\title{
PENGAWASAN TERHADAP DEPOT AIR MINUM ISI ULANG
}

\author{
Samuel Simanjuntak, Mikael Mahin \\ Fakultas Ilmu Sosial Dan Ilmu Politik Universitas Kapuas Sintang \\ Email: mahinmikael@gmail.com \\ Universitas Kapuas Sintang, Jl. Y.C. Oevang Oeray, No.92 Sintang Kalimantan Barat
}

\begin{abstract}
ABSTRAK: Pengawasan terhadap depot air minum isi ulang oleh Puskesmas Tanjungpuri di Kecamatan Sintang Kabupaten Sintang.Menunjukkan bahwa Puskesmas Tanjungpuri di Kecamatan Sintang Kabupaten Sintang sudah melaksanakanPengawasan.Mekanismepengawasan dilaksanakan dalam bentukPengawasan berkalayaitu pemeriksaan lapangan dengan melakukan kunjungan kepemilik depot air minum dilakukan setiap bulannya oleh petugas. Pengawasan rutin yaitu menggunakan formulir Depot Air Minum(DAM) sebagai alatpemantau kualitas higiene sanitasi depot.Persyaratan teknis depot air minum isi ulang, Ada pemilik depot air minum tidak menampilkan laporan hasil uji air minum yang dihasilkan dari laboratorium pemeriksaan kualitas air yang ditunjuk Pemerintah. Pembiayaan pengawasan depot air minum isi ulang dianggarkan dalam Biaya Operasional Kesehatan (BOK) yang bersumber dari APBN dan APBD dengan rincian Rp. 255.000; Per Orang jadi total per tahun sebesar Rp. 510.000. Ada beberapa saran adalah mekanisme pengawasan berkalapemeriksaan lapangan dan pengawasan rutin, hendaknya ditingkat pengawasan dimasa yang akan datang.Pemilik depot air minum diwilayah Kecamatan Sintang untuk menampilkan laporan hasil uji air minum yang dihasilkan dari laboratorium pemeriksaan kualitas air yang ditunjuk Pemerintah secara transparan kepada publik.Pembiayaan pengawasan pada Puskesmas Tanjung Puri Kecamatan Sintang hendaknya dimasa yang akan datang ditingkatkan.
\end{abstract}

Kata Kunci: Pengawasan,Depot Air Minum IsiUlang.

Depot air minum hakikatnya hadir di tengah masyarakat untuk memudahkan masyarakat dalam memenuhi kebutuhan air minum, apalagi melihat kondisi masyarakat yang sebagian besar memanfaatkan teknologi untuk mengefektifkan waktu dalam pemenuhan kebutuhan sehari-hari.Air merupakan salah satu dari kebutuhandasar setiap makhluk hidup. Tanpaair manusiatidak akan pernah merasakan suatu kesegaran dankesejukan dalam jiwanya. Air jugamerupakansebagai penstabil kondisi tubuh. Air tidak hanyadibutuhkan oleh manusia, akan tetapi juga dibutuhkan oleh semua makhluk hidup, diantaranyahewan dan tumbuhtumbuhan. Benda mati sekalipun juga memerlukanair untuk menjagakondisinya seperti kendaraan, yaitu sebagaipendingin suhu mesin berupa radiator.

Kebutuhan akan air bersih semakin bertambah sebagai konsekuensi dari peningkatan jumlah penduduk. Karena sumber-sumber air yang ada tidak lagi mampu memasok air dengan jumlah dan kualitas yang cukup, dikarenakan sungai-sungai yang menjadi sumbernya sudah tercemar berbagai macam limbah, mulai dari buangan sampah organik, rumah tangga, hingga limbah beracun dari industri. Air sangat diperlukan oleh tubuh manusia seperti halnya udara dan makanan, bagi manusia air diperlukan untuk menunjang kehidupan, antara lain dalam kondisi yang layak untuk diminum tanpa menggangu kesehatan. Dalam hal ini kualitas air bersih di Indonesia harus memenuhi persyaratan yang tertuang di dalam Peraturan Menteri Kesehatan RI Nomor 492/Menkes/Per/IV/2010 tentang persyaratan kualitas air minum, dimana air yang digunakan untuk keperluansehari-hari yang kualitasnya memenuhi syarat kesehatandan dapat diminumapabila telah dimasak.

Keperluan sehari-hari terhadap air bersih, berbeda untuk tiap tempat dan untuk tiap tingkatan kehidupan. Semakin tinggi taraf kehidupan semakin meningkat jumlah keperluan akan air. Warga di negara maju lebih banyak memerlukan air minum dari pada di negara berkembang, karena di negara maju semua keperluan air dipenuhi dengan air minum, sedangkan di negara berkembang air minum khusus hanya dipergunakan untuk makan dan minum saja, karena untuk keperluan mencuci dan keperluan lainnya cukup dipenuhi oleh air bersih biasa. Sumber daya alam merupakan segala sesuatu yang muncul secara alami dan dapat digunakan untuk pemenuhan kebutuhan manusia pada umumnya. Dalam Pasal 33 ayat 3 UndangUndang Dasar 1945 menyebutkan bahwa: "Bumi, air dan kekayaan alam yang terkandung didalamnya dikuasai oleh negara dan dipergunakan untuk sebesar-besar kemakmuran rakyat." Maksud isi dari ayat pasal diatas bahwa segala sesuatu mengenai sumber daya alam termasuk di dalamnya air beserta kekayaan alam lainnya milik atau berada dalam wilayah teritori Negara Kesatuan Republik 
Indonesia berarti dikuasai, diatur, dikelola, dan didistribusikan oleh negara atau pemerintah dengan segenap lembaga pengelolanya dipergunakan untuk memakmurkan atau mensejahterakan rakyat Indonesia seluruhnya. Negara mempunyai aturan tersendiri agar usaha eksplorasi sumber daya yang dimiliki tidak disalahgunakan oleh pihak-pihak yang tidak bertanggung jawab. Pengaturan tersebut bertindak dalam fungsi pengawasan dan pemanfaatan yang sebaik-baiknya oleh negara melalui setiap bagian-bagian pemerintah.

Seiring dengan perkembangan peradaban dan populasi, membawa manusia pada era eksplorasi sumber daya sehingga persediaannya terus menerus berkurang secara segnifikan oleh karena itu, pemanfaatannya harus dilakukansecara hati-hati dan efisien agar terus berkesinambungan serta terhindar dari tindakan eksploitasi yang berlebihan. Pemanfaatan dan pemeliharaan sumber daya dapat dilakukan secara rasional dan agar tercapai keadilan maka pelaksanaanya juga harus melalui pihak yang mempunyai wewenang sehingga usaha pemerataan penggunaan sumber daya tersebut terwujud. Dalam hal ini, pihak yang mempunyai wewenang atas pelaksanaan pemerataan dan mengatur secara jelas tentang pemanfaatan dan pemeliharaan sumber daya adalah negara. Lingkungan hidup adalah kesatuan ruang dengan semua benda, daya, keadaan, dan makhluk hidup, termasuk manusia dan perilakunya, yang mempengaruhi alam itu sendiri, kelangsungan perikehidupan, dan kesejahteraan manusia serta makhluk hidup lain. Upaya pengelolaan lingkungan hidup dan upaya pemantauan lingkungan hidup adalah pengelolaan dan pemantauan terhadap usaha dan/atau kegiatan yang tidak berdampak penting terhadap lingkungan hidup yang diperlukan bagi proses pengambilan keputusan tentang penyelenggaraan usaha dan/atau kegiatan. Pembangunan berkelanjutan (sustainable development) merupakan standar yang tidak hanya ditujukan bagi perlindungan lingkungan, melainkan juga bagi kebijaksanaan pembangunan, artinya dalam penyediaan, penggunaan, peningkatan kemampuan sumber daya alam dan peningkatan taraf ekonomi, perlu menyadari pentingnya pelestarian fungsi lingkungan hidup, kesamaan derajat antar generasi, kesadaran terhadap hak dan kewajiban masyarakat, pencegahan terhadap pembangunan yang desktruktif (merusak) yang tidak bertanggung jawab terhadap lingkungan, serta berkewajiban untuk turut serta dalam melaksanakan pembangunan berkelanjutan pada setiap lapisan masyarakat.

Sumber daya yang penting bagi kehidupan masyarakat, air memerlukan perhatian yang lebih dalam hal pemanfaatan dan pemeliharaannya. Di Indonesia sendiri, yang merupakan negara dengan wilayah perairan yang cukup luas kadang masih kurang perhatian dalam hal pemanfaatan dan pemeliharaan sumber daya air bagi kehidupan. Banyak diantara kasus yang terjadi adalah pemanfaatan yang pemeliharaan sumber daya air tersebut menyalahi standar rasional penggunaan dan merugikan banyak pihak. Salah satu kasus penting yang sekarang ini terjadi dan perlu mendapat perhatian lebih adalah mengenai penyediaan air minum bagi masyarakat yang merupakan sumber penting bagi tata kehidupan. Air sendiri dalam kehidupan secara nyata telah tereksplorasi besarbesaran sehingga memungkinkan timbulnya suatu keterbatasan.

Kebutuhan yang vital bagi makhluk hidup terutama manusia adalah kebutuhan akan air. Kebutuhan akan air tersebut diantaranya adalah kebutuhan untuk air minum. Air yang bersih dan sehat merupakan kualifikasi yang sangat diperlukan untuk pemenuhan kebutuhan tersebut. Hal ini dikarenakan pemanfaatan air sebagai air minum secara langsung berkaitan dengan tubuh manusia, sehingga perlu dijaga kualitasnya agar tidak membahayakan tubuh manusia itu sendiri. Air merupakan senyawa kimia yang sangat penting bagi kehidupan makhluk hidup di bumi ini. Fungsi air bagi kehidupan tidak dapatdigantikan oleh senyawa lain. Penggunaan air yang utama dan sangat vital bagi kehidupan adalah sebagai air minum. Hal ini untuk memenuhi kebutuhan air dalam tubuh.

Air adalah zat yang sangat dibutuhkan oleh manusia, dengan terpenuhinya kebutuhan air, maka proses metabolisme dalam tubuh manusia dapat berlangsung dengan baik, sebaliknya jika kekurangan airproses metabolisme akan terganggu dan akibatnya dapat menimbulkankematian. Salah satu upaya pengamanan makanan dan minuman untuk melindungi kesehatan masyarakat adalah pengawasan terhadap kualitasair minum. Hal tersebut dikarenakan air minum merupakan salah satu komponen lingkungan yang mempunyai peranan cukup besar dalam kehidupan. Air dari sumber air harus melalui proses pengolahan terlebih dahulu sampai air tersebut memenuhi syarat kesehatan, baik dari segi kualitas maupun kuantitasnya. Air dan kesehatan merupakan dua hal yang saling berhubungan. Kualitas air yang dikonsumsi masyarakat dapat menentukan derajat kesehatan masyarakat tersebut, khususnya air untuk minum dan makan. Berkaitan dengan kebutuhan akan air minum, selama ini di Kabupaten Sintang memanfaatkan sumber air dari kawasan Bukit kelam yang telah diolah, dengan jumlah dan kualitas yang cukup maka semakin banyak alternatif pemanfaatan air dari sumber lain yang diantaranya adalah air minum isi ulang. Fenomena tersebut yang juga menyebabkan keberadaan bisnis air minum isi ulang yang lebih populer dengan sebutan depot air minum isi ulang semakin meningkat.

Sehubungan dengan pemanfaatan sumber daya alam, agar lingkungan tetap lestari, harus diperhatikan tatanan/tata cara lingkungan itu sendiri. 
Dalam hal ini manusialah yang paling tepat sebagai pengelolanya karena manusia memiliki beberapa kelebihan dibandingkan dengan organisme lain. Manusia mampu merombak, memperbaiki, dan mengkondisikan lingkungan seperti yang dikehendakinya, seperti Manusia mampu berpikir serta meramalkan keadaan yang akan datang; Manusia memiliki ilmu dan teknologi; Manusia memiliki akal dan budi sehingga dapat memilih halhal yang baik. Air bersih yang layak minum, merupakan air yang telah lolos uji kelayakan sesuai aturan yang berlaku. Penyediannya sendiri dapat bersumber dari berbagai macam jenis. Mulai dari air yang disediakan oleh dinas air minum, air minum dalam kemasan, dan yang baru-baru ini muncul dan menjadi alternative penyedia air minum yang lebih murah adalah air minum isi ulang. Pelaksanaan distribusi air minum bersih bagi masyarakat pun tak lepas dari pengawasan Pemerintah melalui Dinas Kesehatan.

Dalam pengaturannya, kualitas air minum yang dapat didistribusikan ke masyarakat ada di dalam Menteri Kesehatan RI Nomor 492/Menkes/ 2010 tentang persyaratan kualitas air minum. Di dalam keputusan tersebut juga telah dijelaskan bahwa pengawasan telah menjadi tanggung jawab dinas kesehatan Kabupaten/Kota. Berdasar kasuskasus yang terjadi sekarang ini, muncul suatu permasalahan tentang penyediaan air minum isi ulang yang depot-depotnya juga telah menjamur dikalangan masyarakat. Dalam prakteknya, depot air minum isi ulang memang menyediakan alternative dalam pemenuhan kebutuhan air minum dengan harga yang relative lebih murah dibandingkan alternative lainnya. Namun, disinyalir bahwa menurut penelitian Badan Pengawas Obat dan Makanan terdapat bakteri yang berbahaya bagi tubuh manusia dalam air minum isi ulang. Dalam penggunaannya, dapat menimbulkan gangguan kesehatan seperti diare. Hal ini disebabkan karena usaha depot air minum masih memiliki banyak permasalahan.

Menimbang dalam rangka meningkatkan derajat kesehatan masyarakat, perlu dilaksanakan berbagai upaya kesehatan termasuk pengawasan kualitas air minum yang dikonsumsi masyarakat. Agar air minum yang dikonsumsi masyarakat tidak menimbulkan gangguan kesehatan maka perlu ditetapkan persyaratan kualitas air minum. Untuk itu pemerintah telah mengeluarkan Keputusan Menteri Kesehatan (Kepmenkes) Nomor 907/ Menkes/SK/VII/2002 tentang Syarat Dan Pengawasan Kualitas Air Minum. Syarat air minum sesuai Permenkes itu harus bebas dari bahan-bahan anorganik dan organik yakni bebas bakteri, zat kimia, racun, limbah berbahaya dan lain sebagainya. Kaitannya dengan rangka meningkatkan derajat kesehatan masyarakat, perlu dilaksanakan berbagai upaya kesehatan termasuk pengawasan kualitas air minum yang dikonsumsi masyarakat tersebut sepenuhnya merupakan tanggung jawab Dinas Kesehatan. Hal-hal yang berkaitan dengan pengawasan kualitas air usaha depot air minum isi ulang sebenarnya berbeda-beda antara satu Kota/ Kabupaten dengan Kota/Kabupaten lainnya, tergantung pelaksanaan Pemerintah Daerahnya. Ada kota/kabupaten yang hanya mewajibkan test laboratorium dan ijin operasional dari Dinas Kesehatan Kota/Kabupaten. Namun ada juga Kota/ Kabupaten yang hanya mewajibkan tes laboratorium saja.

Pengawasan kualitas air bertujuan untuk melindungi masyarakat dari penyakit atau gangguan kesehatan yang berasal dari air minum atau air bersih yang tidak memenuhi persyaratan kesehatan melalui surveilens kualitas air secara berkesinambungan. Dalam rangka memenuhi persyaratan kualitas air minum sebagaimana menurut keputusan Menkes Nomor 907/Menkes/SK/VII/2002 tentang Syarat Dan Pengawasan Kualitas Air Minum, maka perlu dilaksanakan kegiatan pengawasan kualitas air minum yang diselenggarakan secara terus menerus dan berkesinambungan agar air yang digunakan oleh penduduk dari penyediaan air minum yang ada, terjamin kualitasnya, sesuai dengan persyaratan kualitas air minum yang tercantum dalam keputusan ini.

Pengawasan kualitas air minum dalam hal ini meliputi Air minum yang diproduksi oleh suatu perusahaan, baik pemerintah maupun swasta yang didistribusikan ke masyarakat dengan sistem perpipaan. Air minum yang diproduksi oleh suatu perusahaan, baik pemerintah maupun swasta, didistribusikan kepada masyarakat dengan kemasan dan atau isi ulang. Suatu air bersih yang layak minum, merupakan air yang telah lolos uji kelayakan sesuai aturan yang berlaku. Penyedianya sendiri dapat bersumber dari berbagai macam jenis. Mulai dari air yang disediakan dalam kemasan, dan yang baru-baru ini muncul dan menjadi alternatif penyedia air minum yang lebih murah adalah air minum isi ulang. Pelaksanaan distribusi air minum bersih bagi masyarakat pun tak lepas dari pengawasan Pemerintah melalui Dinas Kesehatan.

Pengawasan kualitas air minum secara eksternal merupakan pengawasan yang dilakukan oleh Dinas Kesehatan Kabupaten/Kota khusus untuk wilayah kerja. Pengawasan harus dilakukan dengan intensif agar tidak berdampak dan berisiko pada kesehatan masyarakat yang akan dirasakan dalam jangka panjang apabila ada pelaku usaha yang hanya bertujuan mencari keuntungan tanpamemperhatikan standar yang telah ditetapkan, pelaku usaha mempunyai kewajiban untuk berhatihati dalam memasyarakatkan produk, baik barang maupun jasa.Pengaturannya, kualitas air minum yang dapat didistribusikan ke masyarakat ada di dalam Peraturan Menteri Kesehatan Republik Indonesia Nomor 736/MENKES/PER/VI/2010 
tentang Tata Laksana Pengawasan Kualitas Air Minum Pasal 10 pengertian pelaksanaan pengawasan adalah : (1) Kegiatan pengawasan kualitas air minum meliputi : a. Inspeksi sanitasi dilakukan dengan cara pengamatan dan penilaian kualitas fisik air minum dan faktor resikonya; $b$. Pengambilan sempel air minum dilakukan berdasarkan hasil inspeksi sanitasi; c. Pengujian kualitas air minum dilakukan di laboratorium yang terakreditasi; d. Analisis hasil pengujian laboratorium; e. Rekomendasi untuk pelaksanaan tindak lanjut; dan f. Pemantauan pelaksanaan tindak lanjut. (2) Penyelenggaraan air minum dalam melaksanakan pengawasan internal wajib melaksanakan analisis resiko kesehatan.

Data yang peroleh dari Dinas kesehatan Kabupaten Sintang bahwa sampai tahun 2017 berjumlah 65 Depot air minum yang tersebar di wilayah Kecamatan Sintang, dari jumlah 65 Depot air minum tersebut diklasifikasikan menjadi 34 Depot air minum masuk wilayah Tanjung Puri, 26 Depot air minum masuk wilayah Sungai Durian, dan 5 masuk wilayah Dara Juanti, sedangkan data yang ada pada wilayah Puskesmas Tanjung Puri pada Tahun 2017 adalah sebagai berikut:

\begin{tabular}{|c|l|l|l|l|}
\hline No & Merek Usaha & \multicolumn{1}{|c|}{ Penanggung Jawab } & \multicolumn{1}{|c|}{ Alamat } & Desa/Kelurahan \\
\hline 1 & \multicolumn{1}{|c|}{2} & \multicolumn{1}{|c|}{3} & \multicolumn{1}{c|}{4} \\
\hline 1 & Ris Qua & Helmi & Jl. Darma Putra & Ladang \\
\hline 2 & Airo & Jhoni Umbara, ST & Jl. Lintas Melawi & Ladang \\
\hline 3 & Arai Ro & Suwandi & Jl. Dharma Putra & Akcaya \\
\hline 4 & Victory & Rupina & Jl. Kelam & Akcaya \\
\hline 5 & Jig Qua & Supriyadi & Jl. Kelam Beji & Akcaya \\
\hline 6 & Sequa & Biata Ria Anggalina & Jl. Kelam & Akcaya \\
\hline 7 & Gita Qua & Khairul Maradona & Jl.Kelam & Akcaya \\
\hline 8 & A.88 & Abdurrasyid & Jl. Cadika & Baning Kota \\
\hline 9 & F-Qua & Supardi,ST & Jl.Stadion Baning & Baning Kota \\
\hline 10 & Lun Qua & Lay Sau Tjung & Jl. Oevang Oeray & Baning Kota \\
\hline 11 & Bless Qua & David Sugianto & Jl. Oevang Oeray & Baning Kota \\
\hline 12 & Aisha Qua & Ya Aiduliansyah & Jl. Stadion Baning & Baning Kota \\
\hline 13 & Fahmi Qua & Mochtar Fahmi & Jl.Pangeran Antasari & Tanjung Puri \\
\hline 14 & Rin Qua & Karina Pertamawati & Jl. Akcaya & Tanjung Puri \\
\hline 15 & Aquajaya & Gusti Ariwiyadi & Jl. Akcaya & Tanjung Puri \\
\hline 16 & My Qua & M.Yamin & Jl. Akcaya & Alai \\
\hline 17 & Ci Qua & Suseno & Jl. PKP Mujahidin & Alai \\
\hline 18 & Chell Qua & Suyanto, SE & Jl. Ade Irma Suryani & Alai \\
\hline 19 & Fress Qua & Benarukhan & Jl. M. Saad & Alai \\
\hline 20 & Al-Qohhar & Lukman Al-Qohar & Jl. Akcaya 3 & Alai \\
\hline 21 & Jnd Qua & Suwarni & Jl.Ra Kartini & Alai \\
\hline
\end{tabular}

Sumber: Kantor Puskesmas Tanjung Puri Sintang, April 2018

Pengawasan merupakan salah satu fungsi dalam manajemen suatu organisasi. Dimana memiliki arti suatu proses mengawasi dan mengevaluasi suatu kegiatan. Suatu Pengawasan dikatakan penting karena Tanpa adanya pengawasan yang baik tentunya akan menghasilkan tujuan yang kurang memuaskan, baik bagi organisasinya itu sendiri maupun bagi para pekerjanya. Di dalam suatu organisasi terdapat tipetipe pengawasan yang digunakan, seperti pengawasan Pendahuluan (preliminary control), Pengawasan pada saat kerja berlangsung (cocurrentcontrol), Pengawasan Feed Back (feed back control).Di dalam proses pengawasan juga diperlukan tahap-tahap pengawasan untuk mencapai tujuan yang diinginkan.
Tahap-tahap pengawasan tersebut terdiri dari beberapa macam, yaitu Tahap Penetapan Standar, tahap Penentuan Pengukuran Pelaksanaan Kegiatan, Tahap Pengukuran Pelaksanaan Kegiatan, Tahap Pembandingan Pelaksanaan dengan Standar dan Analisa Penyimpangan dan Tahap Pengambilan Tindakan Koreksi. Menurut Sule dan Saefullah (2005:317) mendefinisikan bahwa: "Pengawasan sebagai proses dalam menetapkan ukuran kinerja dan pengambialan tindakan yang dapat mendukung pencapaian hasil yang diharapkan sesuai dengan kinerja yang telah ditetapkan tersebut". Reksohadiprodjo (2008:63) mengemukakan bahwa: Pengawasan merupakan usaha memberikan petunjuk pada para pelaksana agar mereka selalu bertindak sesuai dengan rencana. 
Sedangkan Sarwoto (2010:94) menyatakan bahwaPengawasan adalah kegiatan manajer yang mengusahakan agar pekerjaan-pekerjaan terlaksana sesuai dengan rencana yang ditetapkan atau hasil yang dikehendaki.

Dari definisi yang telah dikemukakan di atas dapat disimpulkan bahwa pengawasan sebagai salah satu fungsi manajemen. Kepentingannya tidak diragukan lagi seperti halnya dengan fungsi-fungsi manajemen lainnya, karena pengawasan dapat menentukan apakah dalam proses pencapaian tujuan telah sesuai dengan apa yang direncanakan ataukah belum. Manullang (2006:177) mengemukakan bahwa:"Pengawasan adalah dilakukan oleh atasan dari petugas yang bersangkutan. Karena pengawasan semacam ini disebut juga pengawasan vertikal atau formal karena yang melakukan pengawasan ini adalah orang-orang yang berwenang. Pengawasan dapat dipusatkan, dapat didesentralisir tergantung pada karyawannya. Apabila karyawan ahli maka dapat didesentralisir. Kalau banyak karyawan tak ahli seyogyanya dilakukan pusat. Pengawasan dapat dikelompokkan misalnya ke dalam: Pengawasan produksi, yaitu agar hasil produksi sesuai dengan permintaan/pemuasan langganan dalam jumlah, harga, waktu dan servis. Pengawasan persediaan, yaitu menjamin tersedianya bahan dalam jumlah harga, waktu yang tepat sehingga proses produksi tidak terganggu. Pengawasan kualitas, yaitu menjamin agar kualitas hasil produksi, bahan dan bahan proses memenuhi ukuran-ukuran standar yang telah ditentukan. Pengawasan ongkos, yaitu menjamin agar produksi/operasi dijalankan dengan ongkos minimum sesuai dengan standar.

Walaupun pengawasan mahal tetapi diharapkan agar hasil pengawasan akan dapat memperbaiki kedudukan perusahaan karena penjualan dapat didorong karena kualita barang lebih unggul dari saingan, atau harganya bersaingan, dan lain-lain. Di dalam pengawasan perlu pula diperhatikan motivasi. Apabila motivasi kerja tidak cukup percuma saja dilakukan pengawasan, karena akibatnya pelaksana akan berbuat sekehendak hati. Hal ini perlu dihindari agar tidak menimbulkan halhal yang tak diinginkan. Berdasarkan pada batasan pengertian tersebut di atas dapatlah ditarik suatu simpulan bahwa pengawasan adalah suatu usaha pimpinan yang menginginkan agar setiap pekerjan dilaksanakan sebagaimana mestinya. Dengan kata lain bahwa tujuan pengawasan adalah untuk mengetahui dan menilai kenyataan yang sebenarnya tentang objek yang diawasi, apakah sesuai dengan yang semestinya atau tidak.

Terwujudnya tujuan yang dikehendaki oleh organisasi sebenarnya tidak lain merupakan tujuan dari pengawasan. Sebab setiap kegiatan pada dasarnya selalu mempunyai tujuan tertentu. Pengawasan mutlak diperlukan dalam usaha pencapaian suatu tujuan. Menurut Situmorang dan
Juhir (2000:22) maksud pengawasan adalah untuk: Mengetahui jalannya pekerjaan, apakah lancar atau tidak; Memperbaiki kesalahan-kesalahan yang dibuat oleh pegawai dan mengadakan pencegahan agar tidak terulang kembali kesalahan-kesalahan yang sama atau timbulnya kesalahan yang baru; Mengetahui apakah penggunaan budget yang telah ditetapkan dalam rencana terarah kepada sasarannya dan sesuai dengan yang telah direncanakan; Mengetahui pelaksanaan kerja sesuai dengan program (fase tingkat pelaksanaan) seperti yang telah ditentukan dalam planning atau tidak; Mengetahui hasil pekerjaan dibandingkan dengan yang telah ditetapkan dalam planning, yaitu standard.

Menurut Rachman (2009:84) mengemukakan tentang maksud pengawasan, yaitu: Untuk mengetahui apakah segala sesuatu berjalan sesuai dengan rencana yang telah ditetapkan; Untuk mengetahui apakah segala sesuatu telah berjalan sesuai dengan instruksi serta prinsip-prinsip yang telah ditetapkan; Untuk mengetahui apakah kelemahan-kelemahan serta kesulitan-kesulitan dan kegagalan-kegagalannya, sehingga dapat diadakan perubahan-perubahan untuk memperbaiki serta mencegah pengulangan kegiatan-kegiatan yang salah; Untuk mengetahui apakah segala sesuatu berjalan efisien dan apakah dapat diadakan perbaikan-perbaikan lebih lanjut, sehingga mendapat efisiensi yang lebih benar.

Dari kedua pendapat di atas dapat disimpulkan bahwa maksud pengawasan adalah untuk mengetahui pelaksanaan kerja, hasil kerja, dan segala sesuatunya apakah sesuai dengan yang direncanakan atau tidak, serta mengukur tingkat kesalahan yang terjadi, sehingga mampu diperbaiki ke arah yang lebih baik. Pendapat Situmorang dan Juhir (2000:22) mengatakan bahwa tujuan pengawasan adalah: Agar terciptanya aparat yang bersih dan berwibawa yang didukung oleh suatu sistem manajemen pemerintah yang berdaya guna (dan berhasil guna serta ditunjang oleh partisipasi masyarakat yang konstruksi dan terkendali dalam wujud pengawasan masyarakat (kontrol sosial) yang obyektif, sehat dan bertanggung jawab; Agar terselenggaranya tertib administrasi di lingkungan aparat pemerintah, tumbuhnya disiplin kerja yang sehat; Agar adanya keluasan dalam melaksanakan tugas, fungsi atau kegiatan, tumbuhnya budaya malu dalam diri masing-masing aparat, rasa bersalah dan rasa berdosa yang lebih mendalam untuk berbuat hal-hal yang tercela terhadap masyarakat.

Sementara berkaitan dengan tujuan pengawasan, Menurut Sule dan Saefullah (2005:318-319) ada empat tujuan pengawasan tersebut adalah adaptasi lingkungan, meminimumkan kegagalan, meminimumkan biaya, dan mengantisipasi kompleksitas dari organisasi. Maka dapat dijelaskan sebagai berikut: Adaptasi lingkungan, adalah agar perusahaan dapat terus 
menerus beradaptasi dengan perubahan yang terjadi di lingkungan perusahaan, baik lingkungan yang bersifat internal maupun lingkungan eksternal; Meminimumkan kegagalan, adalah ketika perusahaan melakukan kegiatan produksi misalnya perusahaan berharap agar kegagalan seminimal mungkin; Meminimumkan biaya, adalah ketiga perusahaan mengalami kegagalan; isasi.

Antisipasi komplesitas organisasi, adalah agar perusahaan dapat mengantisipasi berbagai kegiatan organisasi yang kompleks.

Sementara pendapat Siswandi (2000:83-84) mengatakan bahwa tujuan pengawasan adalah Pengukuran kepatuhan terhadap kebijakan, rencana, prosedur, peraturan dan hukum yang berlaku; Menjaga sumber daya yang dimiliki organisasi; Pencapaian tujuan dan sasaran yang yang telah ditetapkan oleh Organisasi; Dipercayainya informasi dan keterpaduan informasi yang ada di dalam organisasi; Kinerja yang sedang berlangsung dan kemudian membandingkan kinerja aktual dengan standar serta menetapkan tingkat penyimpangan yang kemudian mencari solusi yang tepat.

Sementara untuk mengetahui apakah sesuatu berjalan sesuai dengan rencana, yang digariskan, mengetahui apakah sesuatu dilaksanakan sesuai dengan instruksi serta asas yang ditentukan, mengetahui kesulitan-kesulitan dan kelemahan-kelemahan dalam bekerja, mengetahui apakah sesuatu berjalan efisien atau tidak, dan mencari jalan keluar jika ternyata dijumpai kesulitan-kesulitan, kelemahan-kelemahan, atau kegagalan ke arah perbaikan. Berdasarkan pendapat para ahli di atas, dapat diketahui bahwa pada pokoknya tujuan pengawasan adalah: (1). Membandingkan antara pelaksanaan dengan rencana serta instruksi-instruksi yang telah dibuat; (2) Untuk mengetahui ada tidaknya kesulitankesulitan, kelemahankelemahan atau kegagalankegagalan serta efisiensi dan efektivitas kerja; (3) Untuk mencari jalan keluar apabila ada kesulitan, kelemahan dan kegagalan, atau dengan kata lain disebut tindakan korektif.

Sule Erni Trisnawati, dan Kurniawan Saefullah (2005:317. Teknik pengawasan, terdapat dua cara untuk memastikan pegawai merubah tindakan/sikapnya yang telah mereka lakukan dalam bekerja, yaitu dengan dilakukannya pengawasan langsung (direct control) dan pengawasan tidak langsung (indirect control). Pengawasan langsung diartikan sebagai teknik pengawasan yang dirancang bangun untuk mengidentifikasi dan memperbaiki penyimpangan rencana. Dengan demikian pada pengawasan langsung ini, pimpinan organisasi mengadakan pengawasan secara langsung terhadap kegiatan yang sedang dijalankan, yaitu dengan cara mengamati, meneliti, memeriksa dan mengecek sendiri semua kegiatan yang sedang dijalankan tadi. Tujuannya adalah agar penyimpangan- penyimpangan terhadap rencana yang terjadi dapat diidentifikasi dan diperbaiki. Pengawasan langsung sangat mungkin dilakukan apabila tingkat kualitas para pimpinan dan bawahannya rendah. Sementara pengawasan tidak langsung diartikan sebagai teknik pengawasan yang dilakukan dengan menguji dan meneliti laporan-laporan pelaksanaan kerja. Tujuan dari pengawasan tidak langsung ini adalah untuk melihat dan mengantisipasi serta dapat mengambil tindakan yang tepat untuk menghindarkan atau memperbaiki penyimpangan. Pengawasan tidak langsung sangat mungkin dilakukan apabila tingkat kualitas para pimpinan dan bawahannya tinggi.

Menurut Sule dan Saefullah (2005:317.) mengemukakan fungsi pengawasan pada dasarnya meruapakan proses yang dilakukan untuk memastikan agar apa yang telah direncanakan berjalan sebagaiamana mestinya. Termasuk kedalam fungsi pengawasan adalah identifikasi berbagai faktor yang menghambat sebuah kegiatan, dan juga pengambilan tindakan koreksi yang diperlukan agar tujuan organisasi dapat tetap tercapai. Sebagai kesimpulan, fungsi pengawasan diperlukan untuk memastikan apa yang telah direncanakan dan dikoordinasikan berjalan sebagaimana mestinya ataukah tidak. Jika tidak berjalan dengan semestinya maka fungsi pengawasan juga melakukan proses untuk mengoreksi kegiatan yang sedang berjalan agar dapat tetap mencapai apa yang telah direncanakan. Fungsi dari pengawasan sandiri adalah:Mempertebal rasa tangung jawab dari pegawai yang diserahi tugas dan wewenang dalam pelaksanan pekerjan.

Mendidik pegawai agar melaksanakan pekerjaannya sesuai dengan prosedur yang telah ditetapkan.

Mencegah terjadinya kelalaian, kelemahan dan penyimpangan agar tidak terjadi kerugian yang tidak diinginkan. Memperbaiki kesalahan dan penyelewengan agar dalam pelaksanaan pekerjan tidak mengalami hambatan dan pemboosanpemborosan.

Pengawasan depot air minum isi ulang bertujuan untuk melindungi masyarakat dari penyakit atau gangguan kesehatan yang berasal dari air minum atau air bersih yang tidak memenuhi persyaratan kesehatan melalui surveilens kualitas air secara berkesinambungan. Dalam rangka memenuhi persyaratan air minum isi ulang sebagaimana menurut keputusan Menkes No : 907/ Menkes/SK/VII/2002, maka perlu dilaksanakan kegiatan pengawasan air minum isi ulang yang diselenggarakan secara terus menerus dan berkesinambungan agar air yang digunakan oleh penduduk dari penyediaan air minum yang ada, terjamin kualitasnya, sesuai dengan persyaratan kualitas air minum yang tercantum dalam keputusan ini. Pengawasan air minum isi ulang dalam hal ini meliputi: 1. Air minum yang diproduksi oleh suatu perusahaan, baik pemerintah maupun swasta yang didistribusikan ke masyarakat dengan sistem 
perpipaan. 2. Air minum yang diproduksi oleh suatu perusahaan, baik pemerintah maupun swasta, didistribusikan kepada masyarakat dengan kemasan dan atau isi ulang. Kegiatan pengawasan ini dilakukan oleh Dinas Kesehatan Kabupaten Sintang yang meliputi: Pengamatan lapangan atau inspeksi sanitasi, Pada air minum perpipaan maupun air minum kemasan, dilakukan pada seluruh unit pengolahan air minum, mulai dari sumber air baku, instalasi pengolahan, proses pengemasan bagi air minum kemasan, dan jaringan distribusi sampai dengan sambungan rumah bagi air minum perpipaan. Pengambilan sampel, Jumlah, frekuensi, dan titik sampel air minum harus dilaksanakan sesuai kebutuhan dengan ketentuan minimal.

Parameter mikrobiologis untuk air minum adalah dengan menggunakan bakteri coli form dan E coli. Apabila dalam pemeriksaan air minum dan ditemukan adanya bakteri tersebut, maka dapat dipastikan bahwa air tersebut telah terkontaminasi oleh tinja manusia dan hewan berdarah panas. Indikator adalah bakteri yang memenuhi persyaratan berikut: Dapat diterapkan untuk semua jenis perairan; Selalu ditemukan bila di dalam perairan tersebut terdapat bakteri pathogen; Jumlahnya sebanding dengan tingkat pencemaran perairan tersebut; Jumlahnya lebih banyak dibandingkan dengan bakteri pathogen; Tidak mengalami pertumbuhan selama berada di perairan; Daya tahan hidupnya lebih lama daripada bakteri pathogen; Tidak ditemukan di dalam perairan yang tidak mengalami pencemaran; Relatif mudah dideteksi di laboratorium; Mempunyai ciri-ciri yang tetap; Tidak berbahaya atau menyebabkan penyakit pada manusia atau hewan.

Disisi lain bentuk Pengawasan kualitas air minum dilaksanakan oleh Puskesmas Tanjungpuri Sintang melalui kegiatan: Inspeksi sanitasi dan pengambilan sampel air termasuk air pada sumber air baku,proses produksi,jaringan distribusi,air minum isi ulang dan air minum dalam kemasan.Pemeriksaan kualitas air dilakukan di tempat/ di lapangan atau di laboratorium.Analisis hasil pemeriksaan laboratorium dan pengamatan lapangan.Memberi rekomendasi untuk mengatasi maslah yang ditemui dari hasil kegiatan a,b,c yang ditujukan kepada pengelola penyediaan air minum.Tindak lanjut upaya penanggulangan/ perbaikan dilakukan oleh pengelola penyedia air minum.Penyuluhan kepada masyarakat.

Sebagaimana diatur dalam Keputusan Menteri Kesehatan Republik Indonesia Nomor 907/ Menkes/SK/VII/2002 Tentang Syarat-Syarat Dan Pengawasan Kualitas Air Minum, pada Pasal 2 ayat 1 dan 2 tentangRuang Lingkup Dan Persyaratanmengatakan bahwa (1) Jenis air minum meliputi :a. Air yang didistribusikan melalui pipa untuk keperluan rumah tangga;b. Air yang didistribusikan melalui tangki air;c. Air kemasan;d. Air yang digunakan untuk produksi bahan makanan dan minuman yangdisajikan kepada masyarakat;harus memenuhi syarat kesehatan air minum. (2) Persyaratan kesehatan air minum sebagaimana dimaksud pada ayat (1)meliputi persyaratan bakteriologis, kimiawi, radioaktif dan fisik.(3) Persyaratan kesehatan air minum sebagaimana dimaksud pada ayat (2)tercantum dalam Lampiran I Keputusan ini.Depot air minum yang saat ini berkembang pesat dirasakan sangat membantu bagi penyediaan air minum bagi masyarakat. Selain harganya yang terjangkau juga karna banyak ditemui di dekat perumahan dan sering sekali memberikan layanan antar tempat. Hal ini dirasakan sebagai salah satu alternative yang sangat efektif dalam membantu masyarakat. Namun Kepercayaan masyarakat terhadap depot air minum sangat bergantugan kepada pengusaha depot itu sendiri,apakah pemilik tersebut mau mengikuti peraturan pemerintahan,seperti peraturan Menteri Kesehatan No.907 Tahun 2002 tentang pengawasan air minum pada depot isi ulang. Sebag a i man a dimaksudkan pada Pasal 1 ayat (1) Keputusan Menteri perindustrian dan Perdagangan Nomor 651 Tahun 2004 tentang Persyaratan Teknis Depot Air Minum dan Pengawasannya. Depot Air Minum adalah usaha industry yang melakukan proses pengolahan air baku menjadi air minum dan menjual langsung kepada konsumen.

Pengaturan persyaratan usaha depot air minum dapat dilihat pada Bab II Persyaratan Usaha Pasal 2 Keputusan Menteri perindustrian dan Perdagangan Nomor 651 Tahun 2004 tentang Persyaratan Teknis Depot Air Minum dan Pengawasannya. Pada Pasal 2 dijelaskan persyaratan usaha yang berbunyi sebagai berikut: Depot Air Minum wajib memiliki Tanda Daftar Industri (TDI) dan Tanda Daftar Usaha Perdagangan (TDUP) dengan nilai investasi perusahaan seluruhnya sampai dengan Rp. 200.000.000,- (dua ratus juta rupiah) tidak termasuk tanah dan bangunan tempat usaha.Depot Air Minum wajib memiliki Surat Jaminan Pasok Air Baku dari PDAM atau perusahaan yang memiliki Izin Pengambilan Air dari Instansi yang berwenang.Depot Air Minum wajib memiliki laporan hasil uji air minum yang dihasilkan dari laboratorium pemeriksaan kualitas air yang ditunjuk Pemerintah Kabupaten/Kota atau yang terakreditasi.

Pada Pasal 3 Keputusan Menteri perindustrian dan Perdagangan Nomor 651 Tahun 2004 tentang Persyaratan Teknis Depot Air Minum dan Pengawasannya menjelaskan tentang air baku yang berbunyi sebagai berikut:Air Baku yang digunakan Depot Air Minum harus memenuhi standar mutu yang ditetapkan dalam Peraturan Menteri Kesehatan.Depot Air Minum harus melakukan Pengawasan secara periodic terhadap mutu air baku,yang ditunjukan dengan hasil uji laboratorium dari Pemasok Pengujian mutu air baku dilakukan minimal: a. Suatu kali dalam tiga 
bulan untuk analisa coliform, b. Dua kali dalam satu tahun untuk analisa kimia dan fisika secara lengkap. Pengujian mutu air baku harus dilakukan di Laboratorium Pemerriksaan Kualitas Air yang ditunjuk oleh Pemerintah Kabupaten/Kota atau yang terakreditasi.Depot Air Minum dilarang mengambil air baku yang berasal dari air PDAM yang ada dalam jaringan distribusi untuk rumah tangga.Transportasi air baku dari lokasi sumber air baku ke Depot Air Minum harus menggunakan tangki pengangkut air yang tara pangan(food grade).

Sementara pada Pasal 6 Keputusan Menteri perindustrian dan Perdagangan Nomor 651 Tahun 2004 tentang Persyaratan Teknis Depot Air Minum dan Pengawasannya menjelaskan tentang mutu air minum yang berbunyi sebagai berikut: Air Minum yang dihasilkan oleh Depot Air Minum wajib memenuhi persyaratan kualitas air minum sesuai yang ditetapkan dalam Peraturan Menteri Kesehatan.Pengujian Mutu produk sesuai persyaratan kualitas air minum wajib dilakukan oleh Depot Air Minum di Laboratorium Pemeriksaan Kualitas Air yang ditunjuk oleh Pemerintah Kabupaten/Kota atau yang terakreditasi sekurangkurangnya 6 (enam) bulan sekali.Hasil pengujian mengenai standar mutu air minum disampaikan kepada Dinas Kabupaten/Kota yang menerbitkan Tanda Daftar Industri.Biaya pengambilan contoh produk dan pengujian sebagaimana dimaksud pada ayat (2) di bebankan pada Depot Air Minum yang bersangkutan.

Keputusan Menteri perindustrian dan Perdagangan Nomor 651 Tahun 2004 tentang Persyaratan Teknis Depot Air Minum dan Pengawasannya Pasal 7 mengatur tentang wadah yang berbunyi sebagai berikut:Depot Air Minum hanya diperbolehkan menjual produknya secara langsung kepada konsumen dilokasi Depot dengan cara mengisi wadah yang diibawa oleh konsumen atau disediakan Depot.Depot Air Minum dilarang memiliki "stock" produk air minum dalam wadah yang siap dijual.Depot Air Minum hanya diperbolehkan menyediakan wadah tidak bermerek atau wadah polos.Depot Air Minum wajib memriksa wadah yang dibawa oleh konsumen dan dilarang mengisi wadah yang tidak layaknpakai,Depot Air Minum harus melakukan pembilasan dan pencucian atau sanitasi wadah dan dilakukan dengan cara yang benar.Tutup wadah yang disediakan oleh Depot Air Minum harus polos/tidak bermerek.Depot Air Minum tidak diperbolehkan memasang segel/ "shrink wrap" pada wadah.

Pada persyaratan yang lain yang berkaitan dengan Surat keterangan laik hygiene diberikan Dinas Kesehatan kepada pengusaha depot air minum yang telah memenuhi syarat standar kualitas air minum. Hal ini dibuktikan dengan adanya hasil uji laboratorium mengenai kandungan bakteri dan kimia yang terdapat dalam air baku dan ataupun air yang dihasilkan depot air minum tersebut. Surat keterangan laik hygiene dikeluarkan oleh Dinas Kesehatan setelah adanya permohonan dari pemilik usaha depot. Pengeluaran surat dilakukan setelah tim petugas yang diketuai sanitarian dari Dinas Kesehatan melakukan pemeriksaan lapangan dan depot air minum tersebut dianggap telah memenuhi persyaratan kualitas air sesuai dengan Peraturan Menteri Kesehatan Nomor 907 Tahun 2002 Tentang Syarat-syarat dan Pengawasan Kualitas Air Minum.

Surat keterangan laik hygiene depot air minum dibedakan menjadi 2 (dua) yaitu:Surat Keterangan Laik Hygiene sementara, masa berlakunya selama 6 (enam) bulan dan dapat diperpanjang.Syarat keterangan Laik Hygiene tetap, masa berlakunya selama 3 (tiga) tahun dan dapat diperbaharui sesuai dengan ketentuan yang berlaku atau menjadi batal bilamana terjadi pergantian pemilik,pindah lokasi/alamat,tutup atau dari hasil pemeriksaan Laboratorium dinyatakan positif mengandung E.Coli atau menyebabkan terjadinya kerancuanan serta jika depot air minum tersebut dianggap tidak lagi laik hygiene. Surat keterangan laik hygiene yang telah diperoleh oleh pengusaha depot air minum harus dipasang di dinding yang mudah dilihat oleh petugas dan masyarakat konsumen.Sebagaimana diatur dalam Keputusan Menteri Kesehatan Republik Indonesia Nomor 907/ Menkes/SK/VII/2002 Tentang Syarat-Syarat Dan Pengawasan Kualitas Air Minum, pada Pasal 10 tentangPembiayaan mengatakan bahwa pemeriksaan sampel air minum sebagaimana dimaksudkan dalamKeputusan ini dibebankan kepada pihak pengelola air minum, pemerintahmaupun swasta dan masyarakat, sesuai dengan peraturan perundang-undanganyang berlaku.

Dalam kamus bahasa Indonesia istilah Pengawasan berasal dari kata awas yang artinya memperhatikan baik-baik, dalam arti melihat sesuatu dengan cermat dan seksama, tidak ada lagi kegiatan kecuali memberi laporan berdasarkan kenyataan yang sebenarnya dari apa yang di awasi Jika memperhatikan lebih jauh, yang menjadi pokok permasalahan dari pengawasan yang dimaksud adalah, suatu rencana yang telah di gariskan terlebih dahulu apakah sudah di laksanakan sesuai dengan rencana semula dan apakah tujuannya telah tercapai. Menurut Prayudi (2000:80) Pengawasan adalah suatu proses untuk menetapkan pekerjaan apa yang di jalankan, dilaksanakan, atau diselenggarakan itu dengan apa yang dikehendaki, direncanakan atau diperhatikan. Sedangkan Menurut Saiful Anwar (2004:127) pengawasan atau kontrol terhadap tindakan aparatur pemerintah diperlukan agar pelaksanaan tugas yang telah ditetapkan dapatmencapai tujuan dan terhindar dari penyimpangan-penyimpangan. Menurut $M$. Manullang (2000:18.) mengatakan bahwa: "Pengawasan adalah suatu proses untuk 
menetapkan suatu pekerjaan apa yang sudah dilaksanakan, menilainya dan mengoreksi bila perlu dengan maksud supaya pelaksanaan pekerjaan sesuai dengan rencana semula.

Menurut Sarwoto (2010:518) fungi pengawasan antara lain: a. sebagai alat untuk melaukan pemeriksaan terhadap ketentuan yang dilakukan apakah sesuai dengan rencana b. sebagai alat untuk menyempurnakan atau perbaikan terhadap penyelewengan dan penyimpangan kegiatan yang tidak sesuai dengan rencana. Hasibuan (2000:226) berpendapat bahwa fungsi pengawasan adalah: a. sebagai alat untuk menentukan standar atau dasar control b. sebagai alat untuk mengukur pelaksanaan c. untuk membandingkan pelaksanaan dengan standard an menentukan defiasiyang ada d. melakukan tindakan perbaikan jika terdapat penyimpangan (defiasi) agar pelaksanaan dan tujuan sesuai dengan rencana.

Pada prinsipnya pengawasan mengandung unsur koreksi yang bersifat pengendalian atau pengaturan terhadap suatu proses atau kegiatan. Maksud dari pengawasan adalah untuk mengatur dan mengendalikan suatu proses denganjalan menilai kegiatan tersebut agar berjalan sesuai dengan ketentuan yang ditetapkan sebelumnya. Menurut Bintora (2005:100) menyebutkan tujuan pengawasan adalah: a. Mengusahakan pelaksanaan rencana berjalan sesuai dengan rencana b. Apabila terdapat penyimpanan maka perlu diketahui seberapa jauh penyimpangan tersebut dan apa sebabnya. c. Dilakukan tindakan koordinatif terdapat adanya penyimpangan-penyimpangan. Guna mencapai tersebut maka S.P Siagian (2000:137) memberikan pedoman atau cara-cara sebagai berikut: pengawasan harus bersifat "Fact finding" yang berarti fungsi pengawasan terhadap pelaksanaan menemukan fakta-fakta tentang bagaimana tugas-tugas dijalankan dalam organisasi itu sendiri.Pengawasan harus bersifat "Preventif" yang berarti bahwa proses pengawasan dijalankan untuk mencegah timbulnya penyimpanganpenyimpangan dan penyelewengan dari rencana yang dietentukan. Pengarahan diarahkan dari masa sekarang,yang berarti kegiatan yang kini dilaksanakan. Pengawasan hanyalah sekedar alat untuk meningkatkan efisien, pengawasan tidak boleh dipandang sebagai tujuan.Karena oengawasan hanya sekedar alat administrasi dan manajemen,maka pengawasan terhadap pelaksanaan itu harus mempermudah tercapainya tujuan.

Proses pengawasan terhadap proses pelaksanaan harus efisien,jangan sampai terjadi pengawasan malah menghambat usaha peningkatan efisien. Pengawasan tidak dimaksudkan untuk terutama untuk menentukan siapa yang salah jika ada ketidak beresan. Pengawasan harus bersifat membimbing agar para pelaksana meningkatkan kemampuan untuk melakukan tugas yang ditentukan baginya.

Berdasarkan lingkupnya, Menurut S.P Siagian (2000:140) pengawasan dibagi dua yaitu: Pengawasan intern,yaitu pengawasan yang dilakukan oleh pejabat dimana pejabat yang melakukan pengawasan tersebut mempunyai hubungan dari segi pekerjaan dengan pihak yang diawasi. Atau jika pengawasan itu dapat diimplementasikan secara luas dimana tidak hanya dilakukan dalam hubungan dinas secara langsung dari segi organisasi atau suatu instansi, tetapi juga diartikan sebagai pengawasan umum tingkat eksekutif. Pengawasan ekstern,yaitu pengawasan yang dilakuakan oleh suatu unit pengawasan yang berada di luar organisasi yang di awasi dan tidak mempunyai hubungan kedinasan dengan pihak yang diawasi. Peraturan Menteri Kesehatan Republik Indonesia Nomor 43 Tahun 2014 Tentang Higiene Sanitasi Depot Air Minum, syarat-syarat air minum adalah tidak berasa, tidak berbau, tidak berwarna, tidak mengandung mikroorganisme yang berbahaya dan tidak mengandung logam berat. Dalam keputusan Menteri Perindustrian dan Perdagangan Republik Indonesia Nomor 736 Tahun 2010 Tentang Tata Laksana Pengawasan Kualitas Air. Sesuai dengan Pasal 5 (lima) untuk mencapai kualitas air minum sesuai persyaratan yang ditetapkan berdasarkan peraturan perundangundangan harus dilakukan pengawasan eksternal dan pengawasan internal.

Sebagaimana dalam Peraturan Menteri Kesehatan Republik Indonesia Nomor 736/ MENKES/PER/VI/2010 Tentang Tata Laksana Pengawasan Kualitas Air Minum, Pasal 6 (enam) pengawasan eksternal dan pengawasan internal dilakukan dengan 2 (dua) cara meliputi: a. Pengawasan berkala; b. Pengawasan atas indikasi pencemaran. Sementara Pasal 7 (tujuh) mengatakan: a. Pengawasan eksternal berkala untuk air minum dengan system jaringan perpipaan dilakukan di titik terjauh pada unit distribusi. b. Pengawasan eksternal berkala untuk depot air minum dilakukan di unit pengisian galon atau wadah air minum. c. Pengawasan eksternal berkala untuk air minum bukan jaringan perpipaan dilakukan pada setiap sarana air minum. Dan Pasal 8 (delapan): a. pengawasan internal berkala untuk air minum dengan system jaringan perpiaan dilakukan di setiap unit produksi dan unit distribusi. b. Pengawasan internal berkala untuk depot air dilakukan di unit produksi dan unit pengisian dan unit pengisian galon atau wadah air minum. c. Pengawasan internal berkala untuk air minum bukan jaringan perpipaan dilakukan pada setiap sarana air minum. 


\section{METODE PENELITIAN}

Metode penelitian yang digunakan dalam penelitian ini adalah jenis penelitian kualitatif. Tujuan dari penelitian ini adalah mengukap fakta, keadaan, fenomena, variabel dan keadaan yang terjadi saat penelitian berjalan dan menyuguhkan apa adanya.Berdasarkan uraian diatas, maka penelitian ini mengunakan jenis penelitian deskriptif kualitatif. Menurut Nawawi (2007:33) metode penelitian deskriptif adalah penelitian yang dilakukan untuk mengetahui atau menggambarkan kenyataan dari kejadian yang diteliti atau penelitian yang dilakukan terhadap variablemandiri atau tunggal. Menurut Arikunto (2002:116) menyatakan subjek penelitian atau sasaran penelitian adalah satuan tertentu yang diperhitungkan sebagai subjek penelitian. Dikalangan peneliti kualitatif, istilah responden atau subjek penelitian disebut dengan informan, yaitu orang yang memberi informasi tentang data yang diinginkan peneliti berkaitan dengan penelitian yang sedang dilaksanakannya. Adapun yang menjadi subjek dalam penelitian ini yang terdiri dari: Kepala Puskesmas Tanjungpuri dengan alasan bahwa salah seorang yang ikut mengawasi Depot Air Minum isi ulang di Kecamatan Sintang. Pelayanan Kesehatan Lingkungan Puskesmas Tanjungpuri dengan alasan bahwa bagian ini yang bertanggung jawab atas persyaratan yang diajukan oleh pemilik Depot Air Minum isi ulang di Kecamatan Sintang. 1 Orang Pemilik Depot Air Minum isi ulang dengan alasan bahwa bagian ini yang bertanggung jawab atas kualitas air Minum isi ulang di Kecamatan Sintang. Teknik Sampling yang digunakan adalah Teknik Purposive Sampling yaitu salah satu teknik non random sampling dimana peneliti menentukan pengambilan sampel dengan cara menetapkan ciriciri khusus yang sesuai dengan tujuan penelitian sehingga diharapkan dapat menjawab permasalahan penelitian.

\section{HASIL PENELITIAN DAN PEMBAHASAN}

Pengawasan kualitas air bertujuan untuk melindungi masyarakat dari penyakit atau gangguan kesehatan yang berasal dari air minum atau air bersih yang tidak memenuhi persyaratan kesehatan melalui surveilens kualitas air secara berkesinambungan, dalam rangka memenuhi persyaratan kualitas air minum, maka perlu dilaksanakan kegiatan pengawasan kualitas air minum yang diselenggarakan secara terus menerus dan berkesinambungan agar air yang digunakan oleh penduduk dari penyediaan air minum yang ada, terjamin kualitasnya, sesuai dengan persyaratan kualitas air minum.Mekanisme Pengawasan Depot Air Minum Isi Ulang melaluiberbagai kegiatan atau program yang dilakukan oleh Puskesmas Tanjung Puri Sintang.

Pengawasan depot air minum isi ulang diwilayah kerjan Puskesmas Tanjungpuri telah melakukanberbagai antara lain :a) Pengawasan berkalaPemeriksaan lapangan dengan melakukan kunjungan keperusahaan depot air minum dilakukan setiap bulannya yangdilakukan oleh petugas.Pengawasan rutin menggunakan formulir Depot Air Minum(DAM) sebagai alatpemantau kualitas higiene sanitasi depot, pemeriksaan awaldengan form DAM akan mendapatkan sertifikat Laik Hygiene Sanitasi bagi yang memenuhi syarat dan digunakan. Pengawasan berkala kamilakukan rutin untukmengawasi depot isi ulang.Kegiatan pengawasan dilaksanakan dua kali dalam setahun dengan melakukankegiatan pengawasan,pengambilan sampel air minum tiapdepot isi ulang, memeriksa bangunan depot,saranapengolahan air minum. Pengawasan rutin menggunakanformulir DAM. sebagai alat pemantau kualitas hygienesanitasi depot, pemeriksaan awal dengan format DAMakan mendapatkan sertifikat Laik Hygiene Sanitasi bagiyang memenuhi syarat dan digunakan untuk mendapatkanizin usaha bagi yang tidak memenuhi syarat akandiberikan pengarahan atau penyuluhan, tindakan tegas jikaada depot air minum isi ulang yang tidak mematuhistandar kualitas air minum, dalam melakukan pengawasan. Berikut ini kegiatan pengawasan berkala Puskesmas Tanjungpuri Sintang mengacu pada pasal 10 Peraturan menteri Kesehatan Republik Indonesia Nomor 736/Menkes/ PER/VI/2010 tentang Tata Laksana pengawasan kualitas air minum, maka dapat dilihat pada tabel berikut:

\begin{tabular}{|c|l|l|}
\hline No & \multicolumn{1}{|c|}{ Kegiatan pengawasan } & \multicolumn{1}{c|}{ Keterangan } \\
\hline 1 & $\begin{array}{l}\text { Inspeksi sanitasi dilakukan dengan cara } \\
\text { pengamatandan penilaian kualitas fisik air } \\
\text { minum dan resikonya }\end{array}$ & $\begin{array}{l}\text { Telah dilakukan oleh Puskesmas Tanjung } \\
\text { Puri }\end{array}$ \\
\hline 2. & $\begin{array}{l}\text { Pengampilan sampel air minum dilakukan } \\
\text { berdasarkan hasil inspeksi sanitasi }\end{array}$ & $\begin{array}{l}\text { Telah dilakukan oleh Puskesmas Tanjung } \\
\text { Puri }\end{array}$ \\
\hline 3. & $\begin{array}{l}\text { Pengujian kualitas air minum dilakukan di } \\
\text { Laboratorium yang terakreditasi }\end{array}$ & $\begin{array}{l}\text { Pengujian dilakukan pada Labkesda, dan } \\
\text { Labkesda belum terakreditasi. }\end{array}$ \\
\hline 4. & Analisis hasil pengujian Laboratorium & $\begin{array}{l}\text { Apabila ada temuan direkomendasi untuk } \\
\text { ditindak lanjut. }\end{array}$ \\
\hline 5. & $\begin{array}{l}\text { Rekomendasi untuk pelaksanaan tindak } \\
\text { lanjut. }\end{array}$ & $\begin{array}{l}\text { Telah dilakukan oleh Puskesmas Tanjung } \\
\text { Puri }\end{array}$ \\
\hline 6. & Pemantauan pelaksanaan tindak lanjut \\
\hline
\end{tabular}


Pengawasan di wilayah Puskesmas Tanjungpuri Sintang melakukan pengawasan depot isi ulangsecara berkala. Melakukan pengawasan berkala dilaksanakan dua kali dalam setahun. Petugas mencatat hasilnya dan laporkanhasil ke Dinas kesehatan Kabupaten Sintang, kemudian Dinas melakukantindakan apabila terjadi masalah pada depot isiulang.Pengawasan berkala yang dilakukan setiap bulan dengan kegiatanpengambilansampel air dan memantau kondisi fisik bangunan untukdiperiksa, apakah hasilnya memenuhi standar atau tidak.Dari beberapa pernyataan yang diungkapkan diatasdapatdiketahui bahwa Puskesmas Tanjungpuri Sintang dalammelakukanpengawasan berkala cukup baik, terbuktidapat terlaksananya pengawasan berkala setiap dua kali dalam setahun.

Pelayanan Kesehatan Lingkungan Puskesmas Tanjungpuri mengatakan selain pengawasan berkala, maka dilakukan Penyuluhan bagi pengeloladepot dan pegawai yang melayani langsung produk air minum.Penyelenggaraan penyuluhan dilakukan oleh Puskesmas Tanjung puri Sintang. Pertemuan berkala untuk pengembangan usaha. Penyuluhan bertujuan untuk membahas permasalahan-permasalahan yang sedang dihadapi. Hasil pemeriksaan berkala terhadap depot air minumdilaporkan Pelayanan Kesehatan Lingkungan Puskesmas Tanjungpuriuntuk selanjutnya dibuat laporan pengawasan dan pemeriksaandepot air minum kepada Dinas Kesehatan Kabupaten Sintang. Apabila ditemukan masalah depot air minum isi ulang maka akan dilakukanpembinaan depot isi ulang tersebutkalau bisa diperbaikidepot isi ulang tersebut bisa dilanjutkan usahanya apabilatidak akan dicabut ijin usahanya.

Hasil pengawasan berkala depotisi ulang oleh Pelayanan Kesehatan Lingkungan Puskesmas Tanjungpuri Sintang pada tahun 2017 adalah sebegai berikut:

\begin{tabular}{|c|l|l|l|}
\hline Nomor & \multicolumn{1}{|c|}{$\begin{array}{c}\text { Nama Depot Air } \\
\text { Minum } \\
\text { Isi Ulang }\end{array}$} & \multicolumn{1}{|c|}{ Alamat } & Hasil Pengawasan \\
\hline 1 & \multicolumn{1}{|c|}{2} & \multicolumn{1}{c|}{ ( } & \multicolumn{1}{c|}{} \\
\hline 1 & Ris Qua & Jl. Darma Putra & Memenuhi Standar \\
\hline 2 & Airo & Jl. Lintas Melawi & Memenuhi Standar \\
\hline 3 & Arai Ro & Jl. Dharma Putra & Memenuhi Standar \\
\hline 4 & Victory & Jl. Kelam & Memenuhi Standar \\
\hline 5 & Jig Qua & Jl. Kelam Beji & Memenuhi Standar \\
\hline 6 & Sequa & Jl. Kelam & Memenuhi Standar \\
\hline 7 & Gita Qua & Jl.Kelam & Memenuhi Standar \\
\hline 8 & A.88 & Jl. Cadika & Memenuhi Standar \\
\hline 9 & F-Qua & Jl.Stadion Baning & Memenuhi Standar \\
\hline 10 & Lun Qua & Jl. Oevang Oeray & Memenuhi Standar \\
\hline 11 & Bless Qua & Jl. Oevang Oeray & Memenuhi Standar \\
\hline 12 & Aisha Qua & Jl. Stadion Baning & Memenuhi Standar \\
\hline 13 & Fahmi Qua & Jl. Pangeran Antasari & Memenuhi Standar \\
\hline 14 & Rin Qua & Jl. Akcaya & Memenuhi Standar \\
\hline 15 & Aquajaya & Jl. Akcaya & Memenuhi Standar \\
\hline 16 & My Qua & Jl. Akcaya & Memenuhi Standar \\
\hline 17 & Ci Qua & Jl. Pkp Mujahidin & Memenuhi Standar \\
\hline 18 & Chell Qua & Jl. Ade Irma Suryani & Memenuhi Standar \\
\hline 19 & Fress Qua & Jl. M. Saad & Memenuhi Standar \\
\hline 20 & Al-Qohhar & Jl. Akcaya 3 & Memenuhi Standar \\
\hline 21 & Jnd Qua & Jl.Ra Kartini & Memenuhi Standar \\
\hline & & & \\
\hline
\end{tabular}

Dari Dua Puluh Satu depot isi ulang di atas semua memenuhi standar haygiene sanitasi setelah dilakukan pemeriksaan, ada beberapa depot isi ulang yang ijin usahanya bermasalah. Setelah diberikan teguran apabila depot isi ulang tidak melakukan perpanjangan ijin danditemukan masalah pada pemerikasaan bulan berikutnya maka akan dilakukan pencabutan ijin usahanya.
Puskesmas Tanjungpuri Sintang melakukan pembinaan terhadap depot isi ulang yang mengalami permasalahan setelah dilakukan pemeriksaan, sepertidepot isi ulang yangdalam pemeriksaan ditemukanbahwa air yang dihasilkan tidak memenuhi standar yangtelah ditetapkan, depot kemudian diberikan suratbahwa air yang dihasilkan tidak memenuhi standarkemudian diberikan 
pembinaan untuk memperbaikialat-alat yang bermasalah.

Bahwa kegiatan pembinaan yang dilaksanakan oleh Puskesmas Tanjungpuri Sintang bisa dikatakan baik. Karena segeradilakukan tindakan pembinaan apabila ditemukan depot isi ulangyang bermasalah. Hal ini tentunya menjadi suatu prestasi yangharus dipertahankanoleh Puskesmas Tanjungpuri Sintang untukmewujudkan kinerja yang lebih baik.Mekanisme Pengawasan Depot Air Minum Isi Ulang. Pedoman yang digunakan para pemilik usaha Depot Air Minum Isi Ulang mengacu Peraturan menteri Kesehatan Republik Indonesia Nomor 736/Menkes/PER/VI/ 2010 tentang Tata Laksana pengawasan kualitas air minum. Sebagaimana yang telah dilaksanakan contoh mekanisme adalah semua air bersih yang masuk dalam proses pengolahan diperiksa mutunya secara fisik dan laboratorium. Sampel diambiloleh petugasBagian Pelayanan Kesehatan Lingkungan Puskesmas Tanjungpuri Sintang,Airminum produksidepot harus sesuai Peraturan menteri Kesehatan Republik Indonesia Nomor 736/Menkes/ PER/VI/2010. Pemeriksaan dilakukan secara periodik danrutin sesuai ketentuan peraturan perundang yang berlaku. Pengujian air minum depot isi ulang dilakukan dua kali dalam setahun bersamaan dengan pengawasan berkala, air yangdihasilkan dari depot isi ulang diuji dilaboratorium untukmengetahui kualitas air yang dihasilkan depot isi ulang,kemudian hasil dari pemeriksaan tersebut diserahkankembali kepada pengusaha depot isi ulang, apabila ditemukan masalah hasil produksinya langsung ditindak lanjut.

Pemilik Depot Air Minum isi ulang dalam upaya memantau kualitas air minum, diwajibkankepada pengusaha untuk menyimpan sedikitnya 1 (satu)unit contoh air minum sebanyak 1 liter dalam keadaanbotol tersegel, untuk setiap proses produksi ataupengiriman air bersih. Contoh ini disimpan di lemari espada suhu dibawah $4 \mathrm{oC}$ selama paling sedikit 1 kali 24 jamkemudian diperiksa mutunya secara fisik danlaboratorium, sampel diambil oleh petugas Bagian Pelayanan Kesehatan Lingkungan Puskesmas Tanjungpuri Sintang. Pengawasanpengujian air minum ini dilakukan setiap dua kali dalam setahun. Hasil pemeriksaan air minum yang dilakukanpemeriksaan di laboratorium disampaikan kepadapengusaha depot, Kepala Puskesmas untuk keperluanpemantauan yang bersangkutan.

Dasar Persyaratan Teknis Depot Air Minum Isi Ulang Sebagaimana dimaksudkan pada Pasal 1 ayat (1) Keputusan Menteri perindustrian dan Perdagangan Nomor 651 Tahun 2004 tentang Persyaratan Teknis Depot Air Minum dan Pengawasannya. Depot Air Minum adalah usaha industry yangmelakukan proses pengolahan air baku menjadi air minum dan menjual langsung kepada konsumen. Pada Pasal 3 Keputusan Menteri perindustrian dan Perdagangan Nomor 651 Tahun 2004 tentang Persyaratan Teknis Depot Air Minum dan Pengawasannya menjelaskan tentang air baku yang berbunyi Air Baku yang digunakan Depot Air Minum harus memenuhi standar mutu yang ditetapkan dalam Peraturan Menteri Kesehatan, Depot Air Minum harus melakukan Pengawasan secara periodic terhadap mutu air baku,yang ditunjukan dengan hasil uji laboratorium dari Pemasok, Pengujian mutu air baku dilakukan minimal: a. Suatu kali dalam tiga bulan untuk analisa coliform, b. Dua kali dalam satu tahun untuk analisa kimia dan fisika secara lengkap, Pengujian mutu air baku harus dilakukan di Laboratorium Pemerriksaan Kualitas Air yang ditunjuk oleh Pemerintah Kabupaten/Kota atau yang terakreditasi, Depot Air Minum dilarang mengambil air baku yang berasal dari air PDAM yang ada dalam jaringan distribusi untuk rumah tangga, Transportasi air baku dari lokasi sumber air baku ke Depot Air Minum harus menggunakan tangki pengangkut air yang tara pangan (food grade).

Puskesmas Tanjungpuri Sintang yang berkaitan dengan Persyaratan Teknis Depot Air Minum Isi Ulang.Diatur secara menyeluruh hal-hal yang terkait teknis depot airminum yang dijadikan sebagai standar dalam pengawasan. Hal yang diawasi berupa (1) Desaindan Kontruksi Depot (2) Bahan baku, Mesin, dan Peralatan (3) Proses Produksi(4) Produk Air Minum (5) Pemeliharaan Sarana Produksi dan Program Sanitasi(6) Karyawan (7) Penyimpanan Air Baku dan Penjualan, dengan tindak lanjutberupa pengamanan barang sementara yang belum memenuhi standar. Dalam pengawasan yang dilakukan olehPuskesmas Tanjungpuri Sintang belumdilakukan secara matang dan maksimal karena keterbatasan jumlah tenaga pengawasan. Belum adanya tindakan seriussebelumdan sesudah industri depot airminum dijalankan oleh pengusaha depot airminum. Sehingga kesalahan yang dilakukan oleh pengusaha depot air minumterus terjadi. Air minum yang merupakan kebutuhan pokok akan membahayakankonsumen karena pemerintah lemah dalam menjamin dan mengawasi prosesindustri depot air minum di Kecamatan Sintang.

Lebih lanjut Kepala Puskesmas Tanjungpuri SintangSurat keterangan laik hygiene depot air minum yaitu:Surat Keterangan Laik Hygiene sementara, masa berlakunya selama 6 (enam) bulan tidak diperpanjang.Syarat keterangan Laik Hygiene tetap, masa berlakunya selama 3 (tiga) tahun dan dapat diperbaharui sesuai dengan ketentuan yang berlaku atau menjadi batal bilamana terjadi pergantian pemilik,pindah lokasi/alamat,tutup atau dari hasil pemeriksaan Laboratorium dinyatakan positif mengandung E.Coli atau menyebabkan terjadinya kerancuanan serta jika depot air minum tersebut dianggap tidak lagi laik hygiene ada pemilik Depot Air Minum masa berlakunya tidak diperpanjang.Surat keterangan laik 
hygiene yang telah diperoleh oleh pengusaha depot air minum tidak dipasang di dinding sehingga sulit dilihat oleh petugas dan masyarakat konsumen.

Pemilik Depot Air Minum Isi Ulang di Wilayah Kecamatan Sintang di ketahui ada beberapa yang tidak memenuhi syarat sebagaimana dalam Keputusan Menteri perindustrian dan Perdagangan Nomor 651 Tahun 2004 tentang Persyaratan Teknis Depot Air Minum dan Pengawasannya misalnya 1. Depot Air Minum wajib memiliki Tanda Daftar Industri (TDI) dan Tanda Daftar Usaha Perdagangan (TDUP) dengan nilai investasi perusahaan seluruhnya sampai dengan Rp. 200.000.000,- (dua ratus juta rupiah) tidak termasuk tanah dan bangunan tempat usaha.2. Depot Air Minum wajib memiliki Surat Jaminan Pasok Air Baku dari PDAM atau perusahaan yang memiliki Izin Pengambilan Air dari Instansi yang berwenang. 3. Depot Air Minum wajib memiliki laporan hasil uji air minum yang dihasilkan dari laboratorium pemeriksaan kualitas air yang ditunjuk Pemerintah Kabupaten/Kota atau yang terakreditasi.

Puskesmas Tanjungpuri Sintang masih ada beberapa pemilik depot tidak memilikiPersyaratan Teknis Depot Air Minum Isi Ulang sesuai dengan Permenkes Nomor 736 / Menkes/PER/VI/2010 tentang Syarat-Syarat dan Pengawasan Kualitas Air. Di dalam peraturan tersebut dimuat persyaratan air Minum dapat ditinjau dari beberapa parameter, yaitu: Parameter fisika: Parameter fisika meliputi bau, kekeruhan, rasa, suhu, warna dan jumlah zat padat terlarut. Tidak Berbau: Air yang berbau dapat disebabkan proses penguraian bahan organik yang terdapat di dalam air. Jernih: Air keruh adalah air mengandung partikel padat, yang dapat berupa zat-zat yang berbahaya bagi kesehatan. Disamping itu air yang keruh sulit didesinfeksi, karena mikroba patogen dapat terlindung oleh partikel tersebut. Tidak Berasa: Air yang tidak tawar mengindikasikan adanya zat-zat tertentu di dalam air tersebut. Suhu: Air yang baik tidak boleh memiliki perbedaan suhu yang mencolok dengan udara sekitar (udara ambien), suhu air minum idealnya $\pm 3^{\circ} \mathrm{C}$ dari suhu udara di atas atau di bawah suhu udara berarti mengandung zat-zat tertentu (misalnya fenol yang terlarut) atau sedang terjadi proses biokimia yang mengeluarkan atau menyerap energi air.

TDS : Total Dissolved Solid/TDS, adalah bahanbahan terlarut (diameter $<10-6-10-3 \mathrm{~mm}$ ) yang berupa senyawa-senyawa kimia dan bahan-bahan lain. Bila TDS bertambah maka kesadahan akan naik. Kesadahan mengakibatkan terjadinya endapan/kerak pada sistem perpipaan.

Parameter Kimia: Parameter kimiawi dikelompokkan menjadi kimia organik dan kimia anorganik. Zat kimia anorganik dapat berupa logam, zat reaktif, zat berbahaya dan beracun serta derajat keasaman $(\mathrm{pH})$. Zat kimia organik dapat berupa insektisida dan herbisida, volatile organis chemicals (zat kimia organik mudak menguap) zat-zat berbahaya dan beracun maupun zat pengikat oksigen. Sumber logam pada air dapat berasal dari kegiatan industri, pertambangan ataupun proses pelapukan secara alamiah, atau karena korosi dari pipa penyalur air. Bahan kimia organik dalam air minum dapat dibedakan menjadi 3 kategori. Kategori 1 adalah bahan kimia yang mungkin bersifat carcinogen bagi manusia. Kategori 2 bahan kimia yang tidak bersifat carcinogen bagi manusia. Kategori 3 adalah bahan kimia yang dapat menyebabkan penyakit kronis tanpa ada fakta carcinogen.

Parameter Mikrobiologis: Indikator organisme yang dipakai sebagai parameter mikrobiologi digunakan bakteri koliform (indicator organism). Bakteri (jenis patogen) merupakan bagian dari mikroorganisme yang dapat menyebabkan penyakit, seperti penyakit saluran pencernaan. Agent ini dapat hidup di dalam berbagai media, hewan, dan manusia secara berantai serta menjalani siklus hidupnya, sehingga merupakan mekanisme untuk mempertahankan hidupnya. Penyakit yang berhubungan dengan air terbagi menjadi empat kelompok, salah satunya, penyakit disebabkan bakteri dalam air setelah air diminum seseorang, kemudian orang tersebut sakit perut atau jatuh sakit. Kontaminasi bahan organik seperti bakteri, dapat terjadi dalam air bersih atau air minum baik jenis patogen (di antaranya bertahan lama di air) maupun apatogen. Organisme indikator memenuhi syarat, antara lain: Terdapat dalam air tercemar dan tidak ada dalam air tidak tercemar. Terdapat dalam air bila ada mikroorganisme pathogen. Jumlahnya berkorelasi dengan kadar polusi.Mempunyai kemampuan bertahan hidup lebih besar daripada patoge., Mempunyai sifat yang seragam dan mantap.Tidak berbahaya bagi manusia dan hewan.

Parameter Radioaktivitas: Zat radioaktivitas dapat menimbulkan efek kerusakan sel. Kerusakan tersebut dapat berupa kematian dan perubahan komposisi genetik. Sel yang mati dapat tergantikan asalkan belum seluruh sel mati, sedangkan perubahan genetis dapat menimbulkan penyakit seperti kanker atau mutasi sel.

Persyaratan Teknis Depot Air Minum Isi Ulang masih belum memenuhi standar, perlu adanya pembinaan dan pengawasan baik dari sisi manajerial juga aspek kualitas produksinya. Persyaratan Teknis Depot Air Minum Isi Ulang. belum ada penyimpangan yang sifatnya berat oleh pelaku usaha depot air minum isi ulang terhadap Persyaratan Teknis Depot Air Minum Isi Ulang, pelaku usaha masih menjalankan sesuai prosedur dalam penyajian depot air minum isi ulang. Pada persyaratan yang lain yang berkaitan dengan Surat keterangan laik hygiene diberikan kepada pengusaha depot air minum yang telah memenuhi syarat standar kualitas air minum. Hal ini dibuktikan 
dengan adanya hasil uji laboratorium mengenai kandungan bakteri dan kimia yang terdapat dalam air baku dan ataupun air yang dihasilkan depot air minum tersebut. Surat keterangan laik hygiene dikeluarkan oleh Dinas Kesehatan setelah adanya permohonan dari pemilik usaha depot. Pengeluaran surat dilakukan setelah tim petugas melakukan pemeriksaan lapangan dan depot air minum tersebut dianggap telah memenuhi persyaratan kualitas air sesuai dengan Persyaratan Teknis Depot Air Minum Isi UlangPermenkes Nomor 736/Menkes/PER/VI/ 2010 tentang Syarat-Syarat dan Pengawasan Kualitas Air.

Pembiayaan merupakan anggaran yangdibutuhkan untuk melaksanakan suatuprogram. Aspek Pembiayaan berperanpenting dalam terlaksananya program pengawasan depot air minum di Wilayah Puskesmas Tanjungpuri Kecamatan Sintang, dalam halini pemerintah tentu harusmengalokasikan anggaran keuangan pelaksanaan pengawasan tiap tahunnya, tanpa keuangan yang terencanadengan baik,tidak akan berjalan program, padahal pengawasan harus ketat dilakukan sebab kecenderungan untuk terjadinya produksi air minum dari depot yang tidak sesuai standar akan berpotensi besar. Biaya yang diperlukansehubungan dengan pelaksanaan pengawasan depot air minum dibebankanpada Anggaran Pendapatan dan Belanja Negara (APBN). Biaya pada program pengawasan depot air minum ini dialokasikan untuk berbagai keperluan diantaranya biaya, transportasi, komunikasi, dan Alokasi biaya lainnya.

Keputusan Menteri Kesehatan Republik IndonesiaNomor 907/MENKES/SK/VII/ 2002 Tentang Syarat-Syarat Dan Pengawasan Kualitas Air Minum Pasal 10 Pembiayaan pemeriksaan sampel air minum sebagaimana dimaksudkan dibebankan kepada pihak pengelola air minum, pemerintah maupun swasta dan masyarakat, sesuai dengan peraturan perundangundangan yang berlaku. Sedangkan pembiayaaan sebagaimana dalam Permenkes Nomor 736 / Menkes/PER/VI/2010 tentang Syarat-Syarat dan Pengawasan Kualitas Air pasal 25 ayat 1 dan 2 mengatakan bahwa Pemerintah dan Pemerintah Daerah harus mengalokasikan anggaran pendapatan dan belanja daerah untuk pembiayaan pelaksanaan pengawasan ekternal kualitas air minum, dan sumber lain yang tidak mengikat sesuai dengan ketentuan peraturan perundang-undangan.

Pembiayaan Pengawasan Depot Air Minum Isi Ulang dianggarkan dalam Biaya Operasional Kesehatan (BOK) yang bersumber dari APBN dan APBD, sedangkan biaya pemeriksaan dibebankan dari Pemilik Depot Air Minum Isi Ulang. Besaran pembiayaan pengawasan depot air minum oleh Puskesmas Tanjungpuri adalah sebagai berikut:

\begin{tabular}{|c|c|c|c|}
\hline No & Jadwal Pengawasan & $\begin{array}{c}\text { Biaya } \\
\text { Operasional } \\
\text { Pengawasan }\end{array}$ & Hasil Pengawasan \\
\hline (1) & (2) & $(3)$ & (4) \\
\hline 1. & Januari S/D Juli 2017 & $\begin{array}{l}\text { Rp. 255.000; } \\
\text { Per Orang. }\end{array}$ & $\begin{array}{l}\text { Peralatan Produksi, Kemasan } \\
\text { Galon, Bahan Baku Air, Dan } \\
\text { Sumber Air Masih ditemui } \\
\text { Beberapa Depot Tidak Memenuhi } \\
\text { Standar. }\end{array}$ \\
\hline 2. & $\begin{array}{l}\text { Juli S/D Desember } \\
\qquad 2018\end{array}$ & $\begin{array}{l}\text { Rp. 255.000; } \\
\text { Per Orang. }\end{array}$ & $\begin{array}{l}\text { Sudah sesuai dengan Permenkes } \\
\text { Nomor } \\
\text { Menkes/PER/VI/2010 tentang } \\
\text { Syarat-Syaratdan } \\
\text { PengawasanKualitas Air dengan } \\
\text { Parameter fisika meliputi } \\
\text { bau,kekeruhan, rasa, suhu, warna } \\
\text { dan jumlah zat padat terlarut. } \\
\text { Tidak ditemukan depot yang } \\
\text { melanggar sebagaimana aturan } \\
\text { yang diatas. }\end{array}$ \\
\hline
\end{tabular}

Berdasarakan tabel diatas bahwa dapat diketahui Pembiayaan Pengawasan Depot Air Minum Isi Ulangyang bersumber dari APBN dan APBD berjumlah Rp. 510.000 Per tahun. Biaya yang minim akan berdampak pada hasil pengawasan yang dilakukan oleh Puskesmas Tanjungpuri Kecamatan Sintang tidak dapat maksimal.. Pembiayaan merupakan anggaran yangdibutuhkan 
untuk melaksanakan suatuprogram. Aspek keuangan berperanpenting dalam terlaksananya program pengawasan depot air minum, dalam hal ini pemerintah tentu harus mengalokasikan anggaran keuanganuntuk pelaksanaan pengawasan tiaptahunnya, tanpa keuangan yang terencana dengan baik, tidak akan berjalan program pengawasan, padahal pengawasan harus ketat dilakukan sebab kecenderungan untuk terjadinya produksi air minum daridepot yang tidak sesuai standar akan berpotensi besar. Biaya yang diperlukan sehubungan dengan pelaksanaan pengawasan depot air minum dibebankan pada Anggaran Pendapatan dan BelanjaDaerah (APBD). Biaya pada program pengawasan depot air minum ini dialokasikan untukberbagai keperluan diantaranya biaya Alokasi biaya lainnya adalahuntuk pelaksanaan di lapangan sepertibiaya transportasi petugas danpemeriksaan air bakudi laboratorium kesehatan lingkungan dinas kesehatan.

Berkaitan dengan pembiayaan berpegang pada aturan sebagaimana diatur dalam Keputusan Menteri Kesehatan Republik Indonesia Nomor 907/Menkes/SK/VII/2002 Tentang SyaratSyarat Dan Pengawasan Kualitas Air Minum, pada Pasal 10 tentangPembiayaan mengatakan bahwa pemeriksaan sampel air minum sebagaimana dimaksudkan dalamKeputusan ini dibebankan kepada pihak pengelola air minum, pemerintahmaupun swasta dan masyarakat, sesuai dengan peraturan perundang-undanganyang berlaku. Namun kenyataan yang penulis dapat pada saat penelitian tidak ada sumbangan biaya dari para pemilik depot di wilayah kecamatan Sintang. Idealnya pemilik depot yang tidak memberikan biaya pengawasan hendaknya diberikan sanksi yang tegas sebagaimana diatur dalam Pasal 11Keputusan Menteri Kesehatan Republik IndonesiaNomor 907/ MENKES/SK/VII/2002TentangSyarat-Syarat Dan Pengawasan Kualitas Air MinumSetiap Pengelola Penyedia Air Minum yang melakukan perbuatan yang bertentangan dengan ketentuan-ketentuan dalam Keputusan ini yang dapat mengakibatkan gangguan kesehatan masyarakat dan merugikan kepentingan umum dapat dikenakan sanksi administratif dan/atau sanksi pidana berdasarkan peraturan yang berlaku.

\section{KESIMPULAN DAN SARAN}

MekanismePengawasan Depot Air Minum Isi Ulang melaluiberbagai kegiatan atau program yang dilakukan oleh Puskesmas Tanjung Puri Sintang sudah dilaksanakan secara baik. Pengawasan berkala Pemeriksaan lapangan dengan melakukan kunjungan keperusahaan depot air minum dilakukan setiap bulannya yang dilakukan oleh petugas. Pengawasan rutin menggunakan formulir Depot Air Minum(DAM) sebagai alatpemantau kualitas higiene sanitasi depot.
Pemilik Depot Air Minum Isi Ulang di Wilayah Kecamatan Sintang di ketahui ada beberapa yang tidak memenuhi syarat. Pemilik Depot Air Minum tidak menampilkan laporan hasil uji air minum yang dihasilkan dari laboratorium pemeriksaan kualitas air yang ditunjuk Pemerintah yang terakreditasi. Pembiayaan Pengawasan Depot Air Minum Isi Ulang dianggarkan dalam Biaya Operasional Kesehatan (BOK) yang bersumber dari APBN dan APBD, sedangkan biaya pemeriksaan dibebankan dari Pemilik Depot Air Minum Isi Ulang. Pengunaan pembiayaan pengawasan dimulai bulan Januari S/ D Juli 2017 dan bulan Juli S/D Desember 2017 dengan rincian Rp. 255.000; Per Orang jadi total per tahun sebesar Rp. 510.000. Biaya yang minim akan berdampak pada hasil pengawasan yang dilakukan oleh Puskesmas Tanjungpuri Kecamatan Sintang tidak dapat maksimal. Mekanisme pengawasan berkalapemeriksaan lapangan dan pengawasan rutin, hendaknya ditingkat pengawasan dimasa yang akan datang.

Pemilik depot air minum diwilayah Kecamatan Sintang untuk menampilkan laporan hasil uji air minum yang dihasilkan dari laboratorium pemeriksaan kualitas air yang ditunjuk Pemerintah secara transparan kepada publik.Pembiayaan pengawasan pada Puskesmas Tanjung Puri Kecamatan Sintang hendaknya dimasa yang akan datang ditingkatkan.

\section{DAFTAR PUSTAKA}

Manullang, 2000.Dasar-Dasar Manajemen, edisi revisi, cetakan ketujuh, Penerbit: Ghalia Indonesia, Jakarta.

M. Manullang, 1995. Dasar-Dasar Manajemen, Ghalia Indonesia, Jakarta.

Nawawi, Hadari. H. 2007. Metode Penelitian Bidang Sosial. Pontianak: Gadjah Mada University Press.

Reksohadiprodjo, Sukanto, 2008. Dasar-dasar Manajemen, edisi keenam, cetakan kelima, Penerbit : BPFE, Yogyakarta.

Sarwoto, 2010. Dasar-Dasar Organisasi dan Manajemen, cetakan keenambelas, Penerbit : Ghalia Indonesia, Jakarta.

Sule Erni Trisnawati, dan Kurniawan Saefullah, 2005. Pengantar Manajemen, edisi pertama, cetakan pertama, Penerbit : Prenada Media Jakarta.

Victor, M. Situmorang, dan Jusuf Juhir, 2000 Aspek Hukum Pengawasan Melekat, Rineka Cipta, Yogyakarta.

Sarwoto, 2010. Dasar-Dasar Organisasi dan Manajemen, cetakan keenam belas, Penerbit : Ghalia Indonesia, Jakarta.

Siswandi dan Indra Iman, 2009. Aplikasi Manajemen Perusahaan, edisi kedua, Penerbit : Mitra Wicana Media, Jakarta. 


\section{PERATURAN PERUNDANG-UNDANGAN}

Undang-Undang Dasar 1945

Peraturan Menteri Kesehatan Republik Indonesia Nomor 43 Tahun 2014 Tentang Higiene Sanitasi Depot air Minum.

Peraturan Menteri Kesehatan RI Nomor 492/ Menkes/2010 Tentang Persyaratan Kualitas Air Minum.

PeraturanMenteriKesehatan Republik Indonesia No. 736/MENKES/PER/VI/2010Tentang
Tata Laksana Pengawasan Kualitas Air Minum.

Keputusan Menteri Kesehatan (Kepmenkes)

Nomor 907/Menkes/SK/VII/2002 tentang

Syarat Dan Pengawasan Kualitas Air Minum.

Keputusan Menteri perindustrian dan

Perdagangan Nomor 651 Tahun 2004 tentang Persyaratan Teknis Depot Air Minum dan Pengawasannya. 